\title{
A sporomorph ecogroup model for the Northwest European Jurassic - Lower Cretaceousi: concepts and framework
}

\author{
O.A. Abbink ${ }^{\star 1}$, J.H.A.Van Konijnenburg-Van Cittert $^{2,3} \&$ H.Visscher ${ }^{1,2}$
}

${ }^{*}$ Corresponding author

${ }^{1}$ TNO-NITG, P.O. Box 80015, NL-3508 TA Utrecht, the Netherlands: o.abbink@nitg.tno.nl

${ }^{2}$ Laboratory of Palaeobotany and Palynology, Utrecht University, Budapestlaan 4, NL-3584 CD Utrecht, the Netherlands: j.h.a.vankonijnenburg@bio.uu.nl, h.visscher@bio.uu.nl

${ }^{3}$ National Museum of Naturl History 'Naturalis', P.O. Box 9517, 2300 RA Leiden, the Netherlands: konijnenburg@naturalis.nl

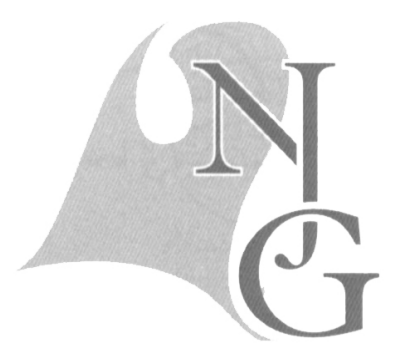

\begin{abstract}
Based on recent vegetation distribution and an integration of macropalaeobotanical and palynological information, a palaeocommunity model is explored that may permit detailed interpretations of quantitative sporomorph distribution patterns in the Jurassic and Early Cretaceous of NW-Europe in terms of changes in palaeoenvironment (sea-level, climate). The conceptual model is based on the recognition of Sporomorph Ecogroups (SEGs) that reflect broad co-existing plant communities, viz. upland, lowland, river, pioneer, coastal, and tidally-influenced SEGs. In successive palynological assemblages, shifts in the relative abundance of SEGs are thought to be indicators of sea-level changes. Climatic changes may be recognised through significant shifts within the quantitative composition of individual SEGs.
\end{abstract}

Keywords: palynology, palaeobotany, Late Jurassic, palaeo-ecology, palaeoclimate, sea-level

\section{Introduction}

Paralic Jurassic sediments in the North Sea form an important economic objective (Brown, 1990; Ziegler, 1990). In these sediments, palynomorphs are the most abundant (micro) fossil group. The marine component in the palynological associations (e.g. dinoflagellate cysts, acritarchs) from these paralic sediments is small or absent, while the terrestrial component (spores, pollen) is high. Consequently, spore/pollen (sporomorph) palynology is increasingly challenged to improve the interpretation of data sets that can be used for dating and characterisation of paralic depositional sequences. The recognition of these depositional sequences is an important aid in hydrocarbon geology. Conventional sporomorph stratigraphy does, however, not provide the required temporal resolution to recognise such sequences (Abbink, 1998). It may even be argued that the required resolution will never be reached due to the relatively slow evolution rate of landplants. Moreover, qualitative analysis does hardly provide information about past environmental changes. Only quantitative data may reflect the relationship between sporomorph assemblages and (spatial, temporal) environmental gradients (e.g. Brugman et al., 1994). Surprisingly few detailed quantitative palynological studies have been carried out on Jurassic paralic sediments (e.g. Whitaker et al., 1992; Hubbard \& Boulter, 1997), whereas palaeoenvironmental interpretation of the identified changes in the composition of Jurassic sporomorph assemblages is still ambiguous.

A realistic interpretation of Jurassic sporomorph signals is largely dependent on the ability to distinguish palaeocommunities by using information on the ecology of the parent plants of quantitatively important spores and pollen. Based on recent vegetation distribution and an integration of environmentally significant macropalaeobotanical and palynological information, in this paper a palaeocommunity model 


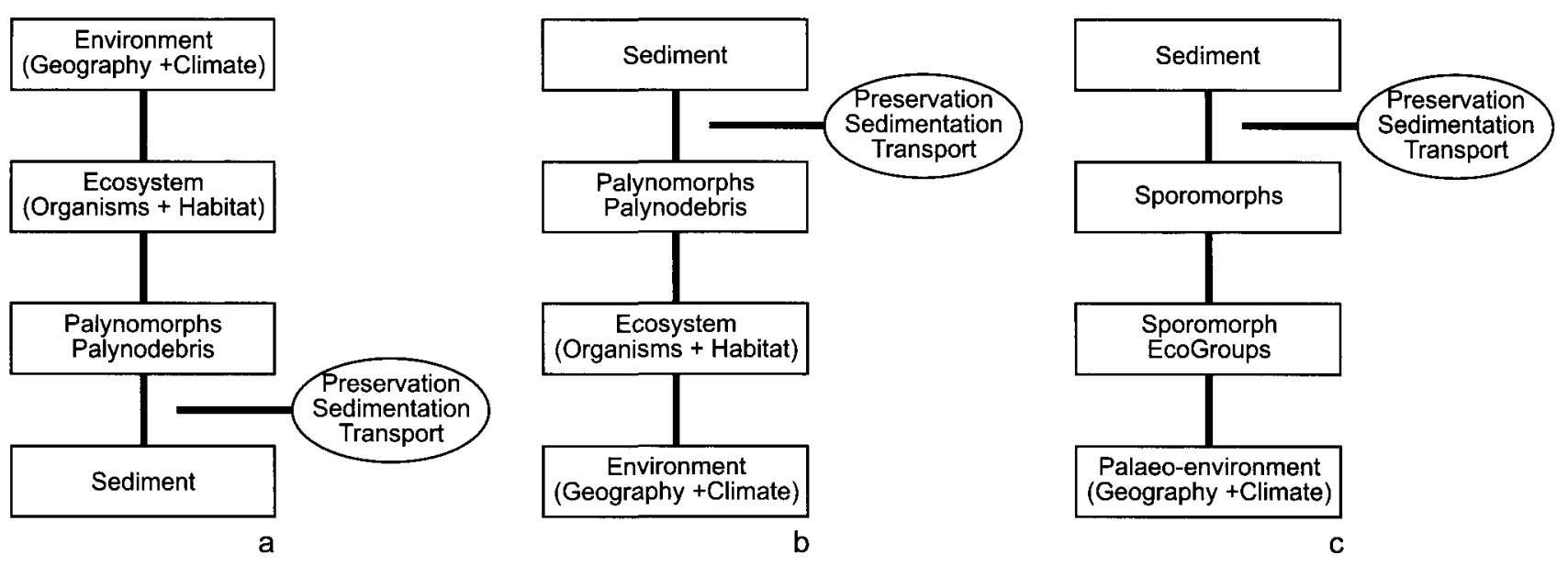

Fig. 1. Simplified diagram of he followed hypotheses for a) present-day situations b) quaternary palaeo-environmental reconstructons and c) the Sporomorph EcoGroup concept (modified after Janssen, 1980; Traverse, 1994; Tyson, 1995).

is explored that may facilitate the interpretation of quantitative sporomorph distribution patterns in the Jurassic and Early Cretaceous of NW Europe in terms of changes in palaeoenvironment. The resulting conceptual 'Sporomorph Ecogroup Model' will applied to and tested against data from a marginal marine, uppermost Callovian - Middle Oxfordian succession in exploration well F17-4 of the Nederlandse Aardolie Maatschappij B.V. (NAM), offshore The Netherlands (Abbink et al., in press).

\section{A sporomorph ecogroup model}

Despite effects of preservation, transportation and sedimentation processes, assemblages of pollen and spores (sporomorphs) reflect the composition of terrestrial plant communities (e.g. Muller, 1959; Chaloner \& Muir, 1968; Traverse, 1988; Tyson, 1995). In Quaternary palynology this relationship is successfully applied in the identification of local and regional environmental change. Quaternary studies strongly benefit from actualistic data and models of the relation between sporomorph signals and environmental gradients (e.g. Birks \& Birks, 1980; Huntley, 1990). In the environmental interpretation of preQuaternary records, the ability to identify sporomorph categories in terms of environmentally significant plant categories becomes a major constraining factor. Going back in time, sporomorphs increasingly represent extinct plant taxa. However, in the Neogene and even in the Paleogene, identification of part of the sporomorph assemblages still enables direct floristic comparisons with extant plant communities. This correlation potential is a sound basis for the introduction of palaeocommunity models that may enable the environmental and climatic interpretation of sporomorph distribution patterns (Poumot, 1989;
Van der Zwan \& Brugman, 1999; Van der Zwan, 2002).

In the Mesozoic, any application of palaeocommunity models is considerably hampered by uncertainties with respect to the botanical affinities of quantitatively important sporomorphs and/or the ecological preference of the extinct parent plants. However, based on actualistic principles, one may assume the presence of distinctive habitat-bounded palaeocommunity types, each of which is characterised by taxa with broadly similar ecological preferences. These palaeocommunity types can serve as a palaeoecological framework for a conceptual Sporomorph Ecogroup model of co-existing sources of dispersed spores and pollen. The term Sporomorph Ecogroup (SEG) is introduced to denote the total of types of dispersed spores and pollen of land plants that reflects the composition of an individual source community. A schematic diagram of this concept is given in Fig. 1.

\section{Definitions of the Furassic-Early Cretaceous SEGs}

In order to define SEGs for the Jurassic - Early Cretaceous and to model the response of SEGs to palaeoenvironmental change, the establishment of an ecological framework for the source communities is necessary. According to Grime (1979) two factors determine the type of plants defining a specific vegetation: stress and disturbance. The variation of the level of stress and disturbance results in three different plant strategies: a competitive strategy (low stress, low disturbance), a stress-tolerating strategy (high stress, low disturbance), and a ruderal strategy (low stress, high disturbance), whereas highly disturbed habitats with severe and continuous stress are not viable as plant habitats (Grime, 1979). 
If we translate these strategies into a conceptual SEG model for the Jurassic - Early Cretaceous landscape of NW Europe, we contemplate one SEG reflecting the vegetation present in the main lowland area, where there is an optimum of nutrients and fresh water (low stress and low disturbance). The lowland plants will follow a competitive strategy and, consequently, the ecological boundaries of the plants reflected by this SEG are determined by less-than-optimum conditions surrounding this lowland area. The plants within the communities reflected by other SEGs will follow a stress-tolerating or ruderal strategy. Seaward, ecological stress is introduced by the influence of salt water (in a tidally-influenced area) and salt spray (in a coastal area), landwards the lack of freshwater and the possible deficiency of nutrients (in the upland area) may introduce ecological stress. Along rivers, periodical submersion and erosion of riverbanks will cause plants to follow a more ruderal strategy. A ruderal strategy will also be employed by first colonisers or pioneer plants. As for plants in the lowland area, the plants within the other ecologically defined areas will also show a competitive strategy, as they are optimised for the ecology of that particular habitat. Following this concept for the Late Jurassic Early Cretaceous of NW Europe the following six
SEGs are taken into consideration (Fig. 2):

(A) Upland SEG, reflecting upland communities: vegetation on higher terrain well above groundwater level that is never submerged by water,

(B) Lowland SEG, reflecting lowland communities; vegetation on plains and/or in fresh water swamps; the plains may (periodically) be submerged by fresh water, resulting in the possible presence of 'wetter' (marsh) and 'drier' taxa in this group; there is no influence of (sea) salt, except, perhaps, under extreme circumstances,

(C) River SEG, reflecting riverbank communities; vegetation on river banks which are (periodically) submerged and subject to erosion,

(D) Pioneer SEG, reflecting pioneer communities: vegetation at instable and recently developed ecospace (e.g. vegetation growing at places that had been submerged by the sea for a longer period),

(E) Coastal SEG, reflecting coastal communities: vegetation growing immediately along the coast, never submerged by the sea but under a constant influence of salt spray, and

(F) Tidally-influenced SEG, reflecting tidally influenced communities: vegetation that is daily influenced by tidal changes (regularly submerged at high tide).
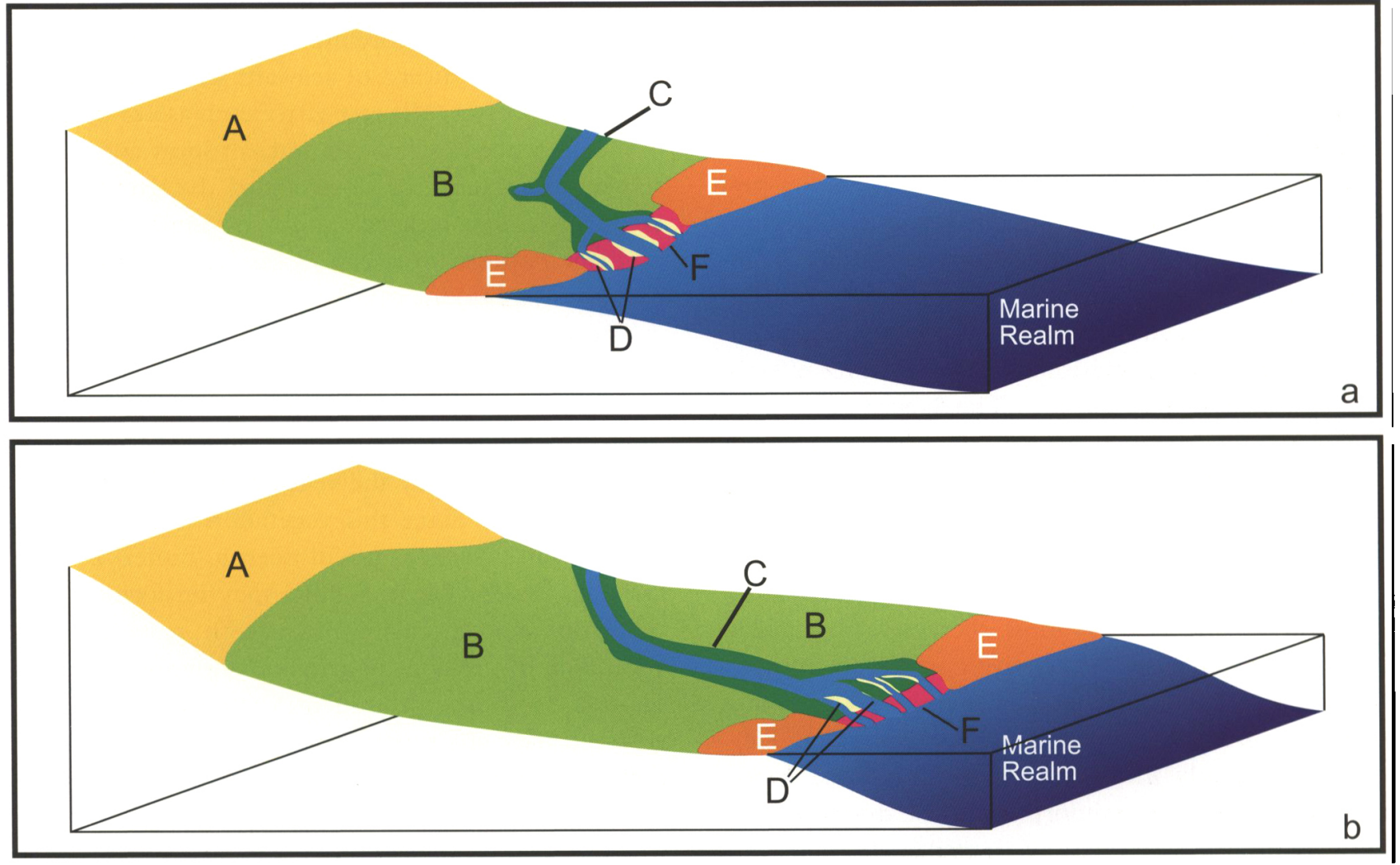

Fig. 2. Schematic representation of the spatial distribution of the SEG. The upper figure (a) depicts the situation during a sea-level high, the lower figure (b) during a sea-level low. $\mathrm{A}=$ Upland, $\mathrm{B}=$ Lowland, $\mathrm{C}=$ River, $\mathrm{D}=$ Pioneer, $\mathrm{E}=$ Coastal and $\mathrm{F}=$ Tidally-influenced SEG. 


\section{Effects of transportation on SEG characteristics}

The fundamental point of consideration in the environmental interpretations of SEG signals is the relationship between the relative abundance of sporomorphs in the sediment and the abundance of their parent plants in plant communities. Apart from differences in sporomorph production, this relationship is subject to the effects of transportation, preservation and sedimentation processes (e.g. Heusser, 1979; Traverse, 1988, 1994; Tyson, 1995). Yet, it is understood that within terrestrial to marginal marine settings the changes within the sporomorph assemblages dominantly reflect changes in the palaeovegetation rather than differences in transportation, preservation or sedimentation (see discussions in e.g. Muller, 1959; Chaloner \& Muir, 1968; Traverse, 1988; Heusser, 1979; Van der Kaars, 1991; Tyson, 1995). Moreover, empirical studies show the relative abundances of sporomorphs to be correlative with distribution of plant communities (e.g. Chaloner \& Muir, 1968; Suc, 1984; Poumot, 1989; Van der Kaars, 1991; Brush \& Brush, 1994; Chmura, 1994).

Although the studies on recent pollen distribution as well as empirical data on fossil sporomorph distribution imply that changes within the sporomorph assemblages can well be interpreted in terms of palaeoenvironmental changes, there are a few, well described effects of transportation that can not be neglected when interpreting the composition of Jurassic - Early Cretaceous SEGs. Since the configuration of the Jurassic - Early Cretaceous landscape of northwestern Europe was largely determined by a low-relief, fluvio-deltaic environmental regime (Ziegler, 1990), sporomorph transportation must have been dominated by water dispersal (Traverse, 1988). In such a setting the most common and widely accepted effect of transportation is the so-called "Neves effect" of Chaloner \& Muir (1968). The Neves effect describes a trend in which the abundances of the broad characters of sporomorph assemblages in depositional environments are generally inversely proportional to the distance of the source communities (see discussions in e.g. Chaloner \& Muir, 1968; Traverse, 1988; Tyson, 1995). One of the most characteristic aspects of the Neves effect is the relative enrichment in marine sediments of hinterland elements of which the source is furthest from the shore. Hinterland elements frequently include bisaccate pollen of gymnosperms. These palynomorphs may be dispersed into the marine environment by air-transport. In an onshore - offshore transect, the decrease of water-transported sporomorphs accounts for a relative increase in wind dispersed sporomorphs (e.g. Heusser, 1979;
Traverse, 1988; Brinkhuis, 1994).

\section{Effects of environmental change on SEG characteristics}

The type of vegetation which is reflected by the SEGs is governed by two principal controls: geography and climate (e.g. Walter, 1973; Chapman, 1977; Grime, 1979; Bakker, 1985; Runhaar et al., 1987; Van der Maarel, 1993). Consequently, in successive palynological assemblages, shifts in (1) the relative abundance of SEGs, and (2) the quantitative composition of individual SEGs are expected to be indicative of changes in geography and/or climate. The major geographical factor inducing palaeoenvironmental changes is generally accepted to be sea-level fluctuations in the Jurassic - Early Cretaceous, taking a maximum temporal resolution of $50 \mathrm{k}$ years $-200 \mathrm{k}$ years into account (e.g. Brown, 1990; Partington et al., 1993a; Herngreen et al., 2000).

\section{Sea-level fluctuations}

Sea-level fluctuations are generally accepted to play a major role in basin infill and provide an important stratigraphic correlation tool, at least on a regional scale (e.g. Haq et al., 1988; Partington et al., 1993a; DeGraciansky, 1999). Within marginal marine to non-marine sediments (coastal/delta plain and upper shelf area), sea-level fluctuations are recorded by cyclic shifts of the shoreline (Galloway, 1989; Vail et al., 1991). A landward or seaward shift of the shoreline influences (1) the respective increase or decrease of the presence of salt water and salt spray and (2) the respective increase or decrease of the groundwater table and related deterioration or improvement of drainage patterns of rivers (Posamentier et al., 1988; Törnqvist, 1993).

The predominant effect of the increase in marine influence due to the invasion of the coastal/delta plain area by marine (salt) waters (sea-level rise) is thought to be an actual reduction of the spatial distribution of the area inhabited by the vegetation reflected by the Lowland SEG. Since this vegetation is not resistant against salt influence, it will need a 'buffer' zone. If the area is very flat, this zone may be formed by a tidally-influenced environment with corresponding vegetation. If the slope of area is slightly steeper or the sea-level rise more prominent, the coastal vegetation is forced back and partly replaces the lowland vegetation (compare Figure 2a and 2b). Similarly, during a sea-level fall the lowland area will expand and there will be a relative increase in the Lowland SEG relative to the Coastal or Tidally-influenced SEGs. Therefore in our model, sea-level causes changes between the SEGs. In particular the ratio of the Coastal SEG ver- 
sus the Lowland SEG is deemed as a proxy for sealevel fluctuations. This implies that sea-level fluctuations can be recognised in fully non-marine environments.

By definition the boundary between the vegetation reflected by the Upland SEG and the Lowland SEG is relatively stable and occurs at or landward of the hinge point. However, since sea-level fluctuations cause changes in river drainage patterns, the abundances of palynomorphs of the Upland SEG (mainly alete bisaccates) are thought to be relatively high during a rising sea-level at the flooding surface. Since these palynomorphs are (also) air-transported, they form a constant input from the upland (Neves effect). The relative enrichment is due to a period of condensation, i.e. a decrease of sediment supply, including water-transported palynomorphs (e.g. Heusser, 1979; Loutit et al., 1988; Brinkhuis \& Zachariasse, 1988).

The Pioneer SEG is considered to have relatively higher abundances around the maximum of the transgression as can be expected for a colonising group of plants (ruderals sensu Grime, 1979).

Although sea-level fluctuations are suggested to predominantly cause changes between the SEGs, the changes of groundwater table and river drainage patterns will result in differences in fresh water availability. Whereas there is still an optimum in nutrients and water and a low stress level for plants in the lowland area, this optimum will convert to one with slightly less wet conditions. These changing conditions will have effect on competitive strategists and, therefore, primarily on the Lowland SEG. Our model suggests that because of declining drainage conditions and a higher groundwater table during a sea-level rise, a moderate increase in wetter elements within the Lowland SEG may be present. Comparably, a sea-level fall may show a slight increase in drier elements of the Lowland SEG.

\section{Other geographic changes}

Changes of the geographic setting include lateral shifts of rivers on a relatively small scale but may also involve on a much larger scale, changes in tectonic regime such as changes in basin subsidence or basin uplift. In particular the abundance of the River SEG in the palynological assemblages will be dependent on the geographical setting. This SEG mainly includes sporomorphs (notably spores) that are directly shed into the water. Hence, changes of river input into the depositional environment will probably be reflected through changes in abundances of sporomorphs of this group. Similarly, the geographic setting also influences the Tidally-influenced SEG. The differences in spatial distribution of tidally-influenced communities along a steep (e.g. fault-controlled) coast, and along a shallow marine deltaic coast are apparent. The other SEGs are suggested not to be affected strongly by small-scale changes in the geographic setting. However, large-scale tectonic reorganisation or continental drift will evidently have rigorous effects on the vegetation.

\section{Climate changes}

Changing climate plays a key-role in reconstructing and understanding past environments. However, the existing palaeoclimatic data for the Jurassic is relatively scattered in time and space (e.g. Hallam, 1985, 1994; Frakes et al., 1992). Therefore, a need exists to establish a well-calibrated 'high resolution' climate curve. Quaternary studies show that the use of palynological data allows the reconstruction of the climate and recognition of climate changes which can be used to introduce such a 'high resolution' climate curve (e.g. Zagwijn \& Hager, 1987; Van der Kaars, 1991; Morley \& Richards, 1993; Targarona, 1997; Van der Zwan \& Brugman, 1999).

Climate controls the level of humidity (precipitation/air-humidity) and temperature. Consequently, principally without a change in the geographical configuration, the availability of light, nutrients and/or water is altered significantly by a climate change. These variables have direct impact on the competitive strategy of plants. Thus, in our model climate changes are considered to significantly change the constituents of the SEGs or to cause dramatic changes of the abundances of the various constituents within a SEG. The plants attributed to the Lowland SEG only have a competitive strategy. Consequently, the Lowland SEG is most sensitive to climate change. In addition, a competitive strategy is followed by the plants within the recognised palaeovegetations reflected by the other SEGs. Therefore, climate changes are also thought to influence the contents of, in particular, the Coastal and Upland SEGs. The other SEGs are considered not to be influenced significantly by a climate change. If, for example, the vegetation producing a River SEG is compared with the present day situation along, for example, the Egyptian Nile, this Ecogroup is considered not to be affected significantly by a climate change, except under extreme conditions, e.g. if a constant water supply fails. Similarly, also the Tidally-influenced SEG is thought not be affected significantly by climate change (e.g. Walter, 1973). In summary, according to our model palaeoclimatic reconstruction and recognition of climatic changes may be achieved by, within a SEG, categorising and plotting the dry vs. wet elements (humidity) and warm vs. cold elements (temperature) (Abbink et al., 2001). 


\section{Ecologies of dominant Jurassic - Early Cretaceous plants}

The Jurassic - Early Cretaceous SEGs are constrained by inferences on the ecologies of the parent plants of frequently occurring sporomorph taxa. A selection of common sporomorph taxa from Northwest Europe (Table 1) is based on an evaluation of published quantitative data sets by e.g. Batten (1978), Birkelund et al. (1978), Boulter \& Windle (1993), Burger (1966), Couper (1958), Dörhöfer (1977), Döring (1965, 1966a and b, 1976), Fensome (1983), Filatoff (1975), Guy-Ohlson (1971, 1986), Herngreen (1971), Herngreen \& de Boer (1974), Herngreen et al. (2000), Heunisch (1993), Hogg (1993), Norris (1969), Srivastava (1987), Tralau (1968), Vakhrameev (1991), Van Amerom et al. (1976), Weiss (1989) and unpublished information available at the Laboratory of Palaeobotany and Palynology. The botanical affinity of the palynological categories is mainly inferred from extensive information on fossil in situ spores and pollen (review by Balme, 1995; specific references in Table 1). Table 2 gives an overview of the common sporomorphs that are considered to be characteristic of the various SEGs.

The ecology of the various groups of parent plants mentioned in Table 1 and 2 is mainly based on published palaeoecological information and partly on comparison with extant relatives of the plant groups (nearest living relatives). Early Cretaceous ecological interpretations are provided by e.g. Batten (1975), Pelzer (1984), Pelzer \& Wilde (1987), Pelzer et al. (1992). Jurassic ecological interpretations are provided by e.g. Alvin (1982), Balme (1995), Filatoff (1975), Francis (1984), Manum et al. (1991), Mohr (1989), Retallack (1997), Reyre (1980), Skog \& Hill (1992), Vakhrameev (1991), Van der Burgh \& Van Konijnenburg-Van Cittert (1984), Van KonijnenburgVan Cittert \& Van der Burgh (1989, 1996), Wesley (1973), Yaroshenko (1985), and unpublished information available at the Laboratory of Palaeobotany and Palynology.

In the following paragraphs, presumed ecologies of parent plant categories are briefly discussed as a background for an inclusion of dispersed sporomorphs in the different SEGs. Conclusions are summarised in Table 2 .

\section{Bryophytes}

Bryophyte spores are represented by Stereisporites and Staplinisporites (p.p.). Although mosses usually grow under more or less humid conditions, some grow in dry places and most can withstand long periods of drought. On the basis of the Jurassic spores, it is impossible to distinguish between mosses favouring humid or dry conditions. However, as the majority of mosses grow near water, we consider the Jurassic spores to belong to the River SEG or possibly to the humid vegetations of the Lowland SEG.

\section{Lycopsids}

Isospores and microspores of lycopsids are represented by the form-genera Densoisporites, Leptolepidites, Lycopodiacidites, Neoraistrickia, Retitriletes, Sestrosporites and Staplinisporites (p.p.). The majority of extant lycopsid species occur in tropical regions, but many species are common in temperate regions and lycopsids have even been found in polar areas. Similar to bryophytes, most Jurassic lycopsid spores can only be tentatively used in ecological interpretations. Based on extant occurrences the lycopsid species may be attributed to the Lowland, River or Tidally-influenced SEGs. Only Densoisporites may be used as a more precise ecological indicator.

Densoisporites is known in situ from Triassic and Early Jurassic Pleuromeiaceae, a heterosporous lycopsid family with a close relationship to the extant Isoetaceae (Raine et al., 1988). Although the family has not (yet) been recorded after the Early Jurassic (Raine et al., 1988; Balme, 1995), types of Densoisporites occurring in younger Jurassic and Cretaceous times (e.g. $D$. velatus) are morphologically closely related to the Triassic and Early Jurassic pleuromeiaceous microspores.

Some members of the Pleuromeiaceae appear to have been facultative coastal halophytes (Retallack, 1975, 1997). It has been suggested that the morphology of Densoisporites microspores is adapted to water dispersal (Yaroshenko, 1985). Furthermore, Couper (1958) reported relatively large amounts of Densoisporites from Jurassic/Cretaceous tidally-influenced sediments. We conclude, therefore, that Densoisporites could well represent an element of Tidally-influenced SEG.

Uvaesporites is known in situ from Selaginellaceae. As these plants are reported to grow under humid conditions, we tentatively assign Uvaesporites to the River SEG. 
Table 1. Selected Late Jurassic and earliest Cretaceous spores and pollen and their botanical affinity

\begin{tabular}{|c|c|}
\hline Spore taxon & Botanical affinity \\
\hline Calamospora mesozoica & Equisetales (Balme, 1995) \\
\hline Cicatricosisporites spp. & Schizaeaceae (Anemia/Mohria-type) (Van Konijnenburg-Van Cittert, 1981, 1991) \\
\hline Concavisporites spp. & Matoniaceae (Van Konijnenburg-Van Cittert, 1993). \\
\hline Concavissimisporites spp & ?Dicksoniaceae/Cyatheaceae (Eboracia; Potonié, 1970) \\
\hline Contignisporites spp. & Pteridaceae (Filatoff and Price, 1988) \\
\hline Cyathidites/Deltoidosporal & Dicksoniaceae, Cyatheaceae, Dipteridaceae, Matoniaceae Van Konijnenburg-Van Cittert, \\
\hline Dictyophyllidites spp. & 1989, 1993; Balme, 1995) \\
\hline Densoisporites spp. & Lycopodiaceae (Selaginella)/Pleuromeiaceae (Knox, 1950; Lundblad, 1950)/(Raine et al., 1988) \\
\hline Duplexisporites problematicus (Striatella) & Pteridaceae (Filatoff, 1975; Filatoff and Price, 1988) \\
\hline Gleicheniidites spp. & Gleicheniaceae (Potonié, 1967) \\
\hline Impardecispora apiverrucata & ?Dicksoniaceae (Venkatachala et al., 1969) \\
\hline Ischyosporites spp. & Schizeaeceae (Lygodium-type) (Van Konijnenburg-Van Cittert, 1981, 1991) \\
\hline Leptolepidites spp. & Lycopodiales (Filatoff, 1975) \\
\hline Lycopodiacidites spp. & Lycopodiales (Filatoff, 1975) \\
\hline Matonisporites spp. & Matoniaceae (Van Konijnenburg-Van Cittert, 1993) \\
\hline Neoraistrickia spp. & Lycopodiales (Filatoff, 1975) \\
\hline Osmundacidites wellmanii & Osmundaceae (Osmunda-type) (Van Konijnenburg-Van Cittert, 1978). \\
\hline Plicatella spp. & Schizaeaceae (Anemia/Mohria-type)(Van Konijnenburg-Van Cittert, 1981, 1991) \\
\hline Punctatisporites spp. / Todisporites spp. & Osmundaceae (Todites-type) (Van Konijnenburg-Van Cittert, 1978). \\
\hline Retitriletes spp. & Lycopodiaceae (Lycopodium-type) (Potonié, 1967) \\
\hline Sestrosporites pseudoalveolatus & ?Lycopodiales \\
\hline Staplinisporites spp. & Mosses and Lycopodiaceae (Potonié, 1967; Boulter \& Windle, 1993) \\
\hline Stereisporites spp. & Mosses (Filatoff, 1975; Boulter and Windle, 1993) \\
\hline Striatella spp. & Pteridaceae (Filatoff and Price, 1988) \\
\hline Trilobosporites spp. & ?Dicksoniaceae (Venkatachala et al., 1969) \\
\hline Uvaesporites spp. & Selaginellaceae (Balme, 1995) \\
\hline Varirugosisporites spp. & possibly Schizaeaceae, Lygodium-type (Filatoff, 1975) \\
\hline
\end{tabular}

\begin{tabular}{|c|c|}
\hline Pollen taxon & Botanical affinity \\
\hline Alete bisaccate pollengrains & Pteridosperms, Conifers (Pinaceae, Podocarpaceae) (Van Konijnenburg-Van Cittert, 1971 \\
\hline \multicolumn{2}{|l|}{ Boulter and Windle, 1993) } \\
\hline Alisporites thomasii & Pteridosperms (Corystospermales) (Van Konijnenburg-Van Cittert, 1971; Balme, 1995) \\
\hline Araucariacites australis & Araucariaceae (Van Konijnenburg-Van Cittert, 1971) \\
\hline Callialasporites spp. & Araucariaceae (Van Konijnenburg-Van Cittert, 1971; Boulter \& Windle, 1993) \\
\hline Cerebropollenites spp. & ?Taxodiaceae (Van der Burgh and Van Konijnenburg-Van Cittert, 1989) \\
\hline Chasmatosporites spp. & ?Cycadales (Tralau, 1968) \\
\hline Clavatipollenites spp. & ?Angiospermae (Balme, 1995) \\
\hline Corollina torosa & Cheirolepidiaceae (Hirmeriella-type) (Van Konijnenburg-Van Cittert, 1987; Balme, 1995) \\
\hline Corollina echinatus & Cheirolepidiaceae (Frenelopsis-type) (Van Konijnenburg-Van Cittert, 1987; Balme, 1995 \\
\hline Eucommiidites minor & $\begin{array}{l}\text { ?; similar grains have a possible suggested relationship with anthophytes (Gnetales or early } \\
\text { angiosperms (Pedersen et al., 1989) }\end{array}$ \\
\hline Eucommiidites troedsonii & Cycadales (Van Konijnenburg-Van Cittert, 1971; Balme, 1995) \\
\hline Exesipollenites spp. & Bennettitales (Harris, 1969, 1974) \\
\hline Monosulcites spp. & $\begin{array}{l}\text { Cycadales, Bennettitales (Potonié, 1967; Van Konijnenburg-Van Cittert, 1971; Boulter \& } \\
\text { Windle, 1993) }\end{array}$ \\
\hline Monosulcites minimus & Ginkgoales (Potonié, 1967; Van Konijnenburg-Van Cittert, 1971; Boulter \& Windle, 1993) \\
\hline Perinopollenites spp. & Taxodiaceae (Van Konijnenburg-Van Cittert, 1971) \\
\hline Quadraeculina anellaeformis & Podocarpaceae (Boulter \& Windle, 1993) \\
\hline Spheripollenites spp. & inner bodies of Taxodiaceae, Cheirolepidiaceae etc. \\
\hline Vitreisporites pallidus & Caytoniales (Pteridosperms) (Van Konijnenburg-Van Cittert, 1971) \\
\hline
\end{tabular}

\section{Equisetales}

Equisetales are represented by Calamospora mesozoica. Extant horsetails usually require a wet habitat (river bank, lowland marsh) and they occur both in (sub)tropical and temperate regions. This also applies to Jurassic representatives. Therefore, the spores are included in the River SEG.

\section{Ferns}

The majority of extant ferns (Filicales) prefer to grow in a shadowy, humid environment. Only a few taxa can bear full sunlight (e.g. Gleicheniaceae). Most ferns are tropical, but they can also be common in temperate forests. In general, therefore, the presence of fern spores indicates more or less humid condi- 
Table 2 Schematic classification of the SEGs

\begin{tabular}{|c|c|c|}
\hline SEG & SPECIES & REMARKS \\
\hline \multirow[t]{2}{*}{ Upland } & Alete Bisaccate Pollengrains & $\begin{array}{l}\text { A few alete bisaccate taxa may not be placed in this group, } \\
\text { i.e. Alisporites thomasii and Vitreisporites pallidus. }\end{array}$ \\
\hline & Quadraeculina anellaeformis & \\
\hline \multirow[t]{24}{*}{ Lowland } & Calamospora spp. & marsh:'wetter'; 'warmer' \\
\hline & Chasmatosporites spp. & 'drier'; 'cooler' \\
\hline & Cicatricosisporites spp. & marsh: 'wetter'; 'warmer' \\
\hline & Clavatipollenites spp. & $\begin{array}{l}\text { 'drier'; 'warmer'; this taxon is questionably attributed } \\
\text { to this SEG. }\end{array}$ \\
\hline & Concavisporites spp. & 'drier'; ‘warmer' \\
\hline & Concavissimisporites spp. & 'drier'; 'warmer' \\
\hline & Contignisporites spp. & 'drier'; 'warmer' \\
\hline & Cycadopites spp. & 'drier'; 'warmer' \\
\hline & Deltoidospora/Dictyophyllidites/Cyathidites spp. & 'drier'; 'warmer' \\
\hline & Duplexisporites problematicus (Striatella) & 'drier'; 'warmer' \\
\hline & Eucommiidites troedsonii & 'drier'; 'warmer' \\
\hline & Exesipollenites spp. & $\begin{array}{l}\text { 'drier'; 'warmer'; due to the xerophytic character of } \\
\text { the motherplant, this taxon may also be placed in } \\
\text { the Coastal SEG. }\end{array}$ \\
\hline & Gleicheniidites spp. & 'drier’; 'warmer’ \\
\hline & Impardecispora apiverrucata & 'drier'; 'warmer' \\
\hline & Ischyosporites spp. marsh: & 'wetter'; 'warmer' \\
\hline & Matonisporites spp. & 'drier'; 'warmer' \\
\hline & Monosulcites minimus & 'drier'; 'cooler' \\
\hline & Monosulcites spp. & 'drier'; 'warmer' \\
\hline & Osmundacidites (B aculatisporites) spp. marsh: & 'wetter'; ‘warmer' \\
\hline & Perinopollenites spp. marsh: & 'wetter'; 'cooler' \\
\hline & Plicatella spp. & 'drier'; 'warmer' \\
\hline & Punctatisporites/T odisporites spp. marsh: & 'wetter'; 'warmer' \\
\hline & Trilobosporites spp. & 'drier'; 'warmer' \\
\hline & Varirugosisporites spp. & 'drier'; 'warmer' \\
\hline
\end{tabular}

\begin{tabular}{ll}
\hline River & Leptolepidites spp. \\
Lycopodiacidites spp. & Neoraistrickia $\mathrm{spp}$. \\
Sestrosporites pseudoalveolatus \\
Staplinisporites spp. \\
Stereisporites spp. \\
Uvaesporites $\mathrm{spp}$. \\
Vitreisporites pallidus
\end{tabular}

\begin{tabular}{lll}
\hline Pioneer & Cerebropollenites spp. & This taxon is questionably attributed to this SEG. \\
\hline Coastal & Araucariacites spp. & 'cooler' \\
& Callialasporites spp. & 'cooler' \\
& Corollina spp. & 'warmer' \\
& Exesipollenites spp. & 'warmer'; see under Lowland SEG. \\
\hline
\end{tabular}

\begin{tabular}{ll}
\hline Tidally-influenced & Alisporites thomasii \\
& Densoisporites spp. \\
& Retitriletes spp.
\end{tabular}

\begin{tabular}{ll}
\hline NOT ATTRIBUTED & $\begin{array}{l}\text { Eucommiidites minor } \\
\text { Spheripollenites spp. }\end{array}$
\end{tabular}

Spheripollenites spp.

REMARKS Ferns spores are here placed in the Lowland SEG, but may also be attributed to the River SEG. Bryophyte spores are here attributed to the River SEG but may also be placed in the Lowland SEG. See text for further explanation. 
tions preferably in warm environments. Also the majority of ferns that have been found in European Jurassic floras are considered to be elements of moist lush vegetation (Harris, 1961; Van der Burgh \& Van Konijnenburg-Van Cittert, 1984; Van KonijnenburgVan Cittert \& Van der Burgh, 1989) often occurring near river banks (Pelzer et al. 1992). Therefore, most fern spores may be characteristic for the Lowland (marsh) or River SEGs. This is particularly the case for spores of Osmundaceae (Osmundacidites, Baculatisporites, Punctatisporites, Todisporites), Schizaeaceae (Cicatricosisporites, Plicatella and to a lesser degree Ischyosporites and Varirugosisporites), Dicksoniaceae, Dipteridaceae and Cyatheaceae (Cyathidites, Concavissimisporites, Deltoidospora, Impardecispora) and Pteridaceae (Contignisporites, Duplexisporites).

Extant Matoniaceae are restricted to mountain slopes in the Malaysian Archipelago, where they are exposed to cold nights and humid, warm days. They protect themselves against these conditions by having a resistant cuticle, a feature that is unknown in other ferns. Most Mesozoic matoniaceous ferns also demonstrate a thick epidermis or a cuticle (Van Konijnenburg-Van Cittert, 1993) and, therefore, we consider them to have grown under somewhat harsh but probably warm/humid conditions. We include their spores (Concavisporites, Deltoidospora, and Matonisporites) in the Lowland SEG.

Extant sun-tolerant Gleicheniaceae grow in vast areas in (sub)tropical regions. Macro-remains of gleicheniaceous ferns (producing Gleicheniidites) were common during Late Jurassic and Cretaceous times, and they may have covered vast lowland areas during these times as well (Harris, 1981: savannah or bracken-covered heath). The spores are included in the Lowland SEG.

\section{Pteridosperms}

The majority of Late Jurassic alete pollen grains represent conifers and belong to the Upland SEG. There are a few exceptions: Vitreisporites pallidus and some species of Alisporites.

Vitreisporites pallidus belongs to the Caytoniales. The Caytoniales are considered to have grown in a deltaic environment during warm Jurassic/Cretaceous times (Harris, 1964). Pelzer (1984) believed that they grew on the transition between the floodplain and backswamp peats, while Van Konijnenburg-Van Cittert \& Van der Burgh (1989) believed them to be plants of moist lush vegetation. Anyway, they indicate a warm and rather wet environment. We include the pollen in the River SEG.

Alisporites (especially $A$. thomasii) has been record- ed in situ from Pachypteris-type of pteridosperms that belong to the Corystospermales. The subtropical genus Pachypteris was widespread during Middle and Late Jurassic times, and disappeared in the Early Cretaceous (Vakhrameev, 1991). Some species, e.g. P. papillosa, have probably been large-sized bushes that formed mangrove thickets along river mouths inundated by tides (Harris, 1964, 1983). Therefore, we include Alisporites thomasii in the Tidally- influenced SEG.

\section{Ginkgoales, Cycadales, Bennettitales}

Most fossil pollen grains of the Ginkgoales and the Cycadales belong to Monosulcites and/or Cycadopites. The pollen can usually only be distinguished under SEM or TEM (Hill, 1990), although in general ginkgoalean pollen grains are slightly smaller than those of cycads (Van Konijnenburg-Van Cittert, 1971).

Ginkgo biloba is the only extant representative of the Ginkgoales. It is a deciduous tree that lives in temperate regions and can withstand severe frost. In Mesozoic times, the Ginkgoales were a more diverse group that was mainly restricted to temperate regions, but occasionally representatives were found in the subtropical belt. Pollen grains from these Mesozoic Ginkgoales are usually rather small and can be included in Monosulcites minimus Cookson (Van Konijnenburg-Van Cittert, 1971).

Extant Cycadales occur in tropical regions and are usually adapted to withstand droughts (thick leathery leaves with thick cuticles and protected stomata), although a few species occur in rain forests. In the Mesozoic, cycads were more diverse and certain extinct taxa, such as the Nilsoniaceae, were lowland plants in subtropical areas with warm and frost-free weather (Van Konijnenburg-Van Cittert \& Van der Burgh, 1989; Vakhrameev, 1991). Pollen of some of the Mesozoic cycads may occasionally correspond to Monosulcites minimus, but the majority can be included in larger species of Chasmatosporites, Monosulcites or Cycadopites.

Many pollen grains of the extinct Bennettitales also belong to Monosulcites/Cycadopites, but are distinguished by their large size and a more spindle-like shape (elongate-elliptical outline; Couper, 1958; Harris, 1969; Van Konijnenburg-Van Cittert, 1971). Bennettitaleans grew, like the Mesozoic cycads, mainly in the subtropical belts with warm and frost-free weather (Vakhrameev, 1991). Some taxa yielding Monosulcites were probably restricted to deltaic areas (Harris, 1969; Van Konijnenburg-Van Cittert \& Van der Burgh, 1989), others preferred a drier microclimate 
and grew on slopes adjoining marine basins (Vakhrameev, 1991) or in upland vegetation (Van Konijnenburg-Van Cittert \& Van der Burgh, 1989). Their thicker cuticles with protected stomata also indicate that they were adapted to withstand periods of drought or salt influence. Also in Cretaceous sediments there is evidence for occurrences in upland areas (Watson \& Sincock, 1992) or even in dry savannahs (Harris, 1973).

Despite the possibility of other habitats, we consider that most Late Jurassic to Early Cretaceous Monosulcites/Cycadopites pollen grains have originated from Ginkgoales, Cycadales, and Bennettitales that grew in lowland vegetation. Consequently, this pollen is included in the Lowland SEG.

Apart from Monosulcites/Cycadopites, some bennettitalean plants also produced pollen corresponding to Exesipollenites (plants with the bisexual Williamsoniella flowers and Nilssoniopteris leaves; Harris, 1969, 1974; Van Konijnenburg-Van Cittert, 1971). It is likely that these plants preferred a dry microclimate even with some salt influence (Batten, 1976; Watson \& Sincock, 1992). Therefore, we include Exesipollenites in the Lowland SEG, with a possible extension to the Coastal SEG.

\section{Conifers}

Apart from some pteridosperms, genera of several conifer families, e.g. (extant) Pinaceae and Podocarpaceae, are characterised by alete bisaccate pollen grains. Because of a general lack of identifying characters among Mesozoic coniferalean alete bisaccates, it is usually difficult to indicate their botanical affinity at a family level.

Podocarpaceae, which also produce Quadraeculina anellaeformis pollen, occur nowadays only in (sub)tropical areas of the southern hemisphere, often on mountain slopes. In the Mesozoic they were common on the northern hemisphere as well, again restricted to (sub)tropical belts. Most extant Pinaceae occur in temperate zones in relatively dry environments, and many taxa can withstand severe cold. In general one may say that also in the Mesozoic these conifer families inhabited relatively dry areas of upland forest (Vakhrameev, 1991). A high frequency of alete bisaccates of the type produced by Pinaceae and Podocarpaceae can therefore be considered to be indicative of Upland SEGs.

Callialasporites and Araucariacites species (e.g. A. australis) may be associated with the Araucariaceae (Van Konijnenburg-Van Cittert, 1971; Boulter \& Windle, 1993). Practically all large types of Late Jurassic and Early Cretaceous Inaperturopollenites pollen are also considered to have araucarian affinities (Balme, 1995). Extant Araucariaceae are often a dominant element in forests in Australia and South America. Their leathery leaves and thick cuticles are an adaptation to long periods of drought and cold conditions. They frequently grow near shores as they can withstand the influence of salt wind.

In Jurassic/Cretaceous times, a high frequency of Araucariacites/Callialasporites is, in general, correlated with a warm climate without large seasonal amplitudes (Reyre, 1980; Mohr, 1989). Evidence from macrofossils indicates that araucarian trees often grew in forests not far from the coast (Harris, 1979; Barale \& Flamand, 1982; Vakhrameev, 1991). Therefore, large quantities of Callialasporites and Araucariacites pollen may be indicative of Coastal SEGs.

Species of Corollina have been recorded in situ from various representatives of Jurassic and (Early) Cretaceous Cheirolepidiaceae. Within this family, two subfamilies can be distinguished: the Hirmeriellae or Hirmeriella - group (mainly but not exclusively occurring in the Jurassic), and the Frenelopsidae or Frenelopsis - group (common in the Cretaceous). Although the pollen grains of both groups belong to Corollina, they can be distinguished at a species level. Corollina torosus belongs to the Hirmeriellae, while Corollina echinatus belongs to the Frenelopsidae. The ecology of this palynologically important family (Corollina often forms a major part of palynological assemblages), has long been subject of debate. In general, one can conclude that Cheirolepidiaceae were drought resistant, thermophilous shrubs and trees that required at least a subtropical climate (Francis, 1983; Vakhrameev, 1991). They were never dominant in cold climatic regions. Most authors agree that the Jurassic Hirmeriella species were probably coastal plants (Vakhrameev, 1970, 1991; Batten, 1973, 1975; Jung, 1974; Alvin, 1982; Watson, 1988), either growing on sandy bars and coastal islands or even as mangroves. During the Cretaceous, the Cheirolepidiaceae probably occupied a whole range of warm habitats (Batten, 1976; Alvin, 1982; Francis, 1983), from river banks for some Hirmeriella species, to arid, even desert conditions for most Frenelopsis and Pseudofrenelopsis species. Especially the latter two taxa show many xeromorphic stem and cuticle characters indicative of an adaptation to (seasonal) arid habitats (Broutin \& Pons, 1975; Alvin, 1982; Watson, 1988). Although most authors believe that these xeromorphic characters are related to real xerophytism rather than halophytism (e.g. Alvin, 1982), others favour coastal habitats for at least some Frenelopsis species (Doludenko \& Reymanowna, 1978; Pons \& Broutin, 
1978; Pons, 1979). In conclusion, we consider the presence of large numbers of Corollina torosus (or morphologically related species) to be indicative of Coastal SEGs, while in Cretaceous times Corollina echinatus (and related species) should be placed either in the Coastal or in the Lowland SEG.

Perinopollenites has been recorded from Elatides, an extinct representative of the Taxodiaceae (Van Konijnenburg-Van Cittert, 1971; Harris, 1979; Van Konijnenburg-Van Cittert \& Van der Burgh, 1989; Balme, 1995). These thermophilic (Vakhrameev, 1991) conifers are well known from Late Jurassic and Early Cretaceous (Wealden) deposits, that are associated with wet lowlands with repeated marine transgressions (Pelzer et al., 1992). Species of Elatides were also found in Middle Jurassic sediments were they are considered to be plants of lush vegetation (Harris, 1979). Also some extant members of the Taxodiaceae prefer humid environments. We therefore place Perinopollenites in the Lowland SEG.

Cerebropollenites has been found in situ (Van Konijnenburg-Van Cittert \& Van der Burgh, 1989), in a polliniferous cone of unknown affinities although there are certain similarities to Elatides cones. Therefore, a taxodiaceous nature is a possibility. Other authors recognise similarities with Tsuga-like pollen (Balme, 1995), and thus point to an affinity with the Pinaceae. Despite this taxonomic uncertainty, the fact that Cerebropollenites occurs in large quantities immediately after a regression (Couper, 1958; Abbink, personal observation), could well be evidence of a pioneer nature of the parent plants. We therefore place Cerebropollenites in the Pioneer SEG.

Although the form-genus Spheripollenites may also include completely preserved palynomorphs, Jurassic forms identified as Spheripollenites are likely to be inner (nexine) bodies of coniferous pollen such as Corollina and Perinopollenites. Several authors even believe that the presence of large numbers of Spheripollenites together with large numbers of Corollina, indicate a more strongly developed annual dry season (Alvin, 1982; Mohr, 1989). Hence the forms might be added to the Lowland SEG. However, because of the taxonomic and ecological uncertainties of incomplete pollen, we refrain from applying Spheripollenites in the SEG model.

\section{Eucommiidites}

Eucommiidites minor has never been recorded in situ. However, the species has been found in dispersed Jurassic and Cretaceous pollen organs and seeds (Van Konijnenburg-Van Cittert, 1971; Pedersen et al., 1989). The precise botanical affinity of these pollen organs and seeds is uncertain. The seeds suggest a close relationship with the Antophytes, a broad category comprising Bennettitales, Pentoxylales, Gnetales and Angiospermae. On the other hand, Jurassic cones containing Eucommiidites troedsonii grains are thought to have Cycadalean affinities (Van Konijnenburg-Van Cittert, 1971). No precise ecological conclusions can be drawn from the presence of this species.

\section{Possible angiosperms}

Clavatipollenites is thought to be related to the first angiosperms (Pedersen et al., 1991, 1994). Although not much is known about the ecology of the plants, we questionably assign this species to the Lowland SEG, based on the sedimentary evidence (Brenner, 1963; Pedersen et al., 1991).

\section{Conclusions}

The presented SEG model is considered to allow the identification of palaeoenvironmental changes, in particular sea-level fluctuations and climate changes based on quantitative distribution patterns of Jurassic - Early Cretaceous sporomorph assemblages. Variations between the various SEGs permit the recognition of sea-level fluctuations. Significant shifts within the SEGs, especially within the Lowland SEG are considered to reflect climate changes.

The SEG model provides the possibility to recognise depositional sequences in Jurassic - Early Cretaceous shallow marine to even non-marine settings exclusively on the basis of palynology. Hence, the model may provide a new and powerful tool for correlation between non-marine to shallow marine sequences and marine (standard) sequences (Abbink et al., this volume). In addition, this approach allows detailed understanding of the palaeoenvironment and a glance at the Jurassic Earth System (Abbink et al., 2001).

\section{Acknowledgements}

The material and financial support of TNO-NITG (Utrecht), NAM B.V. (Assen), and the Laboratory of Palaeobotany and Palynology (Utrecht University) is gratefully acknowledged. Furthermore, we wish to thank Henk Brinkhuis and Michiel van Houte (Utrecht) for their comments and discussions. Johan van der Burgh (Utrecht) is thanked for his help on (palaeo)botanical aspects. 


\section{References}

Abbink, O.A., 1998. Palynological investigations in the Jurassic of the North Sea region. LPP Contribution Series 8: $192 \mathrm{pp}$.

Abbink, O.A., Targarona, J., Brinkhuis, H. \& Visscher, H., 2001. Late Jurassic to earliest Cretaceous palaeoclimatic evolution of the Southern North Sea. Global and Planetary Change, 30: 231256.

Alvin, K.L., 1982. Cheirolepidiaceae: Biology, structure and palaeoecology. Review of Palaeobotany and Palynology 37: 7198.

Bakker, K., 1985. Algemene inleiding. In: Bakker, K. (ed.), Inleiding tot de oecologie, Utrecht: 2-24.

Balme, B.E., 1995. Fossil in situ spores and pollen grains: An annotated catalogue. Review of Palaeobotany and Palynology 87: 1323.

Barale, G. \& Flamand, D., 1982. La paléoflore de l'Oxfordien de la région de Châteauroux (Indre). Bulletin de Bureau de Recherches Géologiques et Minières 2, 1: 255-261.

Batten, D.J., 1973. Palynology of Early Cretaceous soil beds and associated strata. Palaeontology 16: 399-424.

Batten, D.J., 1975. Wealden palaeoecology from the distribution of plant fossils. Proceedings of the Geologist's Association, 85: 433458.

Batten, D.J., 1976. Wealden of the Weald - a new model. Proceedings of the Geologist's Association 87: 431-433.

Batten, D.J., 1978. Early Cretaceous to Middle Jurassic miospores and palynofacies of the Northwest European continental shelf. In: Thusu, B. (ed.), Distribution of biostratigraphically dinoflagellate cysts and miospores from the Northwest European continental shelf and adjacent area. Publication of the Institutt for Kontinentalsokkelundersoekelser 100: 97-100.

Birkelund, T., Thusu, B. \& Vigran, J., 1978. Jurassic-Cretaceous biostratigraphy of Norway, with comments on the British Rasenia cymodoce Zone. Palaeontology $21:$ 31-63.

Birks, H.J.B. \& Birks, H.H., 1980. Quaternary palaeoecology, Arnold, London: $289 \mathrm{pp}$.

Boulter, M.C. \& Windle, T., 1993. A reconstruction of some Middle Jurassic vegetation in Northern Europe. Special Papers in Palaeontology 49: 125-154.

Brenner, G.J., 1963. The spores and pollen of the Potamic Group of Maryland. Department of Geology, Minerology and Water Resources Bulletin 27: 1-215.

Brinkhuis, H., 1994. Late Eocene to Early Oligocene dinoflagellate cysts from the Priabonian type-area (Northeast Italy); biostratigraphy and palaeoenvironmental interpretation. Palaeogeography, Palaeoclimatology, Palaeoecology 107: 121-163.

Brinkhuis, H. \& Zachariasse, W.J., 1988. Dinoflagellate cysts, sealevel changes and planktonic formaninifera across the $\mathrm{K} / \mathrm{T}$ boundary at Al Haria, Northwest Tunisia. Marine Micropaleontology 13: 153-191.

Broutin, J. \& Pons, D., 1975. Nouvelles précisions sur la morphologie et la phytodermologie de quelques rameaux du genre Frenelopsis Schenk. Comptes rendus du $100 \mathrm{e}$ Congrès National des Sociétés Savantes, Paris 1975, II: 29-46.

Brown, S., 1990. Jurassic. In: Glennie, K.W. (ed.), Introduction to the Petroleum Geology of the North Sea: 219-254.

Brugman, W. A., van Bergen, P. F. \& Kerp, J. H. F., 1994. A quantitative approach to Triassic palynology: the Lettenkeuper of the Germanic Basin as an example. In: Traverse, A. (ed.), Sedimentation of Organic Particles. Cambridge University Press, Cambridge: 409-429.

Brush \& Brush, 1994. Transport and deposition of pollen in an estuary: signature of the landscape. In:Traverse, A. (ed.), Sedimen- tation of Organic Particles. Cambridge University Press, Cambridge: 33-46.

Burger, D., 1966. Palynology of the uppermost Jurassic and lowermost Cretaceous strata in the eastern Netherlands. Leidse Geologische Mededelingen, 35: 209-276.

Chaloner, W.G. \& Muir, M., 1968. Spores and Floras. In: Murchison, D. and Westall, T.S. (eds). Coal and coal bearing strata. Oliver and Boyd, Edinburgh: 127-146.

Chapman, V.J., 1977. Ecosystems of the world 1. Wet coastal ecosystems. Elsevier Scientific Publishing Company, Amsterdam, Oxford, New York: $428 \mathrm{pp}$.

Chmura, G.L., 1994. Palynomorph distribution in marsh environments in the modern Mississippi Delta plain. Bulletin of the Geological Society of America 106: 105-714.

Couper, R.A., 1958. British Mesozoic microspores and pollen grains. A systematic and stratigraphic study. Palaeontographica, Abteilung B 103: 75-179.

DeGraciansky, P.-C., Hardenbol, J., Jacquin, T., Vail, P.R. \& Farley, M.B., 1999. Jurassic sequence chronostratigraphy/ biochronostratigraphy. In: De Graciansky et al. (eds), Mesozoic-Cenozoic Sequence Stratigraphy of European Basins. Special Publication of the Society of Economists, Paleontologists and Mineralogists 60: Charts 6 and 7.

Doludenko, M.P. \& Reymanowna, M., 1978. Frenelopsis harrisii sp. nov. from the Cretaceous of Tajikistan, USSR. Acta Palaeobotanica 19:3-12.

Dörhöfer, G., 1977. Palynologie und Stratigraphie der Bückeberg-Formation (Berriasium-Valanginium). Geologisches Jahrbuch Serie A, 42: 3-122.

Döring, H., 1965. Die sporenpaläontologische Gliederung des Wealden in Westmecklenburg. Geologie, 14, Beihefte 47:1-118.

Döring, H., 1966a. Die sporenstratigraphischen Gliederung des Unterkreide im nördlichen Mitteleuropa. In: Döring, H., Krutzsch, W., Mai, D.H., \& Schulz, E., Erläuterungen zu den sporenstratigraphischen Tabellen vom Zechstein bis zum Oligozän. Abhandlungen des Zentrales Geologisches Institut Berlin 5: 46-60.

Döring, H., 1966b. Die sporenstratigraphischen Gliederung des Malm im nördlichen Mitteleuropa. In: Döring, H., Krutzsch, W., Mai, D.H. \& Schulz, E. (eds), Erläuterungen zu den sporenstratigraphischen Tabellen vom Zechstein bis zum Oligozän. Abhandlungen des Zentrales Geologisches Institut Berlin 5: 61-78.

Döring, H., 1976. Biostratigraphische Untersuchungen im Malm und Wealden der Insel Rügen. Jahrbuch für Geologie 5/6: 711-783.

Fensome, R.A., 1983. Miospores from the Jurassic - Cretaceous boundary beds, Aklivik Range, Northwest Territories, Canada. Ph.D. Thesis, University of Saskatchewan: $762 \mathrm{pp}$.

Filatoff, J., 1975. Jurassic palynology of the Perth Basin, Western Australia. Palaeontographica, Abteilung B, 154: 1-113.

Filatoff, J. \& Price, P.L., 1988. A pteridacean spore lineage in the Australian Mesozoic. Memoirs of the Association of Australian Palaeontologists 5: 89-124.

Frakes, L.A., Francis, J.E. \& Syktus, J.I., 1992. Climate Modes of the Phanerozoic, Cambridge University Press: $274 \mathrm{pp}$.

Francis, J.E., 1983. The dominant conifer of the Jurassic Purbeck Formation, England. Palacontology 26: 277-294.

Francis, J.E., 1984. The seasonal environment of the Purbeck (Upper Jurassic) fossil forests. Palaeogeography, Palaeoclimatology, Palaeoecology 48: 285-307.

Galloway, W.E., 1989. Genetic Stratigraphic Sequences in Basin Analysis I, Architecture and Genesis of Flooding-Surface Bounded Depositional Units. Bulletin of the American Association of Petroleum Geologists 73: 125-142.

Grime, J. P., 1979. Plant Strategies \& Vegetation Processes, Sheffield: $222 \mathrm{pp}$. 
Guy-Ohlson, D.J.E., 1971. Palynological investigations in the Middle Jurassic of the Vilhelmsfailt boring, southern Sweden. Publications of the Institute of Mineralogy, Palaeontology and Quaternary Geology, University of Lund, Sweden 168: $104 \mathrm{pp}$.

Guy-Ohlson, D.J.E., 1986. Jurassic palynology of the Vilhelmsfält Bore No. 1, Scania, Sweden. Toarcian-Aalenian. Swedish Museum Natural History, Section Palaeobotany: $127 \mathrm{pp}$.

Hallam, A., 1985 A review of Mesozoic climates. Journal of the Geological Society of London 142: 433-445.

Hallam, A., 1994. Jurassic climates as inferred from the sedimentary and fossil record.p.79-88. In: Allen, J.R.L., Hoskins, B.J., Sellwood, B.W., Spicer, R.A. and Valdes P.J. (eds), Palaeoclimates and their Modelling. The Royal Society, Chapman, London: $140 \mathrm{pp}$.

Haq, B.U., Hardenbol, J. \& Vail, P.R., 1988. Mesozoic and Cenozoic chronostratigraphy and cycles of sea level change. In: Wilgus, C. K., Hastings, B. S., et al. (eds), Sea Level Changes; An Integrated Approach. Special Publication of the Society of Economists, Paleontologists and Mineralists 42: 71-108.

Harris, T.M., 1961. The Yorkshire Jurassic flora, I. ThallophytaPteridophyta. British Museum (Natural History), London: 211 pp.

Harris, T.M., 1964. The Yorkshire Jurassic flora, II. Caytoniales, Cycadales and Pteridosperms. British Museum (Natural History), London: $191 \mathrm{pp}$.

Harris, T.M., 1969. The Yorkshire Jurassic flora, III. Bennettitales. British Museum (Natural History), London: $186 \mathrm{pp}$.

Harris, T.M., 1973. The strange Bennettitales. 19th Sir Albert Charles Seward Memorial Lecture, 1971; Birbal Sahni Institute of Palaeobotany, Lucknow, India.

Harris, T.M., 1974. Williamsoniella lignieri; its pollen and the compression of spherical pollen grains. Palaeontology, 17: 125-148.

Harris, T.M., 1979. The Yorkshire Jurassic flora, V. Coniferales. British Museum (Natural History), London: $166 \mathrm{pp}$.

Harris, T.M., 1981. Burnt ferns from the English Wealden. Proceedings of the Geologist's Association 92: 47-58.

Harris, T.M., 1983. The stem of Pachypteris papillosa (Thomas and Bose) Harris. Botanical Journal of the Linnean Society 86: 149159.

Herngreen, G.F.W., 1971. Palynology of a Wealden Section (Lower Cretaceous) in the 'Carrière de Longueville', the Boulonnais (France). Review of Palaeobotany and Palynology, 12: 271-302.

Herngreen, G.F.W. \& De Boer, K.F., 1974. Palynology of Rhaetian, Liassic and Dogger strata in the Eastern Netherlands. Geologie en Mijnbouw 53: 343-368.

Herngreen, G.F.W., Kerstholt, S.J. \& Munsterman, D.K., 2000. Callovian-Ryazanian ('upper Jurassic') palynostratigraphy of the Central North Sea Graben and Vlieland Basin, the Netherlands. Mededelingen Nederlands Instituut voor Toegepaste Geowetenschappen TNO 63: 1-99.

Heunisch, C., 1993. Zur Palynologie des Oberen Jura in Nordwestdeutschland. Bericht des Niedersächsischen Landesamt für Bodenforschung, Hannover: 1-37.

Heusser, L., 1979. Spores and pollen in the marine realm. In: Haq, B.U. and Boersma, A. (Eds). Introduction to marine micropalaeontology. Elsevier, New York: 327-339.

Hill, C.R., 1990. Ultrastructure of in situ fossil cycad pollen from the English Jurassic, with a description of the male cone $A n$ drostrobus balmei sp. nov. Review of Palaeobotany and Palynology 65: 165-173.

Hogg, N. M., 1993. A palynological investigation of the Scalby Formation (Ravenscar, Group, Middle Jurassic) and adjacent strata from the Cleveland Basin, North East Yorkshire. Ph. D. Thesis, Sheffield: 233 pp.

Hubbard, RnN.L.B. \& Boulter, M.C., 1997. Mid Mesozoic floras and climates. Palaeontology 40: 43-70.
Huntley, B., 1990. Studying global change: the contribution of Quaternary palynology. Palaeogeography, Palaeoclimatology, Palaeoecology 82: 53-62.

Janssen, C. R., 1980. Some remarks on facts and interpretation in Quaternary palyno-stratigraphy. Bulletin de l'Assocation Francaise pour l'Etude du Quaternaire 17: 171-176.

Jung, W., 1974. Die Konifere Brachyphyllum nepos Saporta aus den Solnhofener Plattenkalken (unteres Untertiton), ein Halophyt. Mitteilungen der Bayerischen Staatssammlung für Palaeontogie und Historische Geologie 14: 49-58.

Knox, E.M., 1950. The spores of Lycopodium, Phylloglossum, Selaginella and Isoëtes and their value in the study of microfossils of Palaeozoic origin. Transactions and Proceedings of the Botanical Society Edinburgh 35: 209-357.

Loutit, T.S., Hardenbol, J., Vail, P.R. \& Baum, G.R., 1988. Condensed sections: the key to age dating and correlation of continental margin sequences. In: Wilgus, C. K., Hastings, B. S., et al. (eds), Sea Level Changes; An Integrated Approach. Special Publication of the Society of Economists, Paleontologists and Mineralogists 42: 183-216.

Lundblad, B., 1950. Studies in the Rhaeto-Liassic floras of Sweden. Kungl. Svenska Vetenskapsakademiens Handlingar 4, 1, 8: $1-82$.

Manum, S.B., Bose, M.N., and Vigran, J.O., 1991. The Jurassic flora of Andøya, Northern Norway. Review of Palaeobotany and Palynology, 68: 233-256.

Mohr, B.A.R., 1989. New palynological information on the age and environment of Late Jurassic and Early Cretaceous vertebrate localities of the Iberian Peninsula (eastern Spain and Portugal). Berliner Geowissenschaftlischen Abhandelungen, Reihe A 106: 291-301.

Morley, R.J. \& Richards, K., 1993. Graminae cuticles: a key indicator of Late Cenozoic climate change in the Niger Delta. Review of Palaeobotany and Palynology, 77: 119-127.

Muller, J., 1959. Palynology of recent Orinoco delta and shelf sediments, reports of the Orinoco Shelf expedition, Vol. 5. Micropalaeontology 5, 1: 1-32.

Norris, G., 1969. Miospores from the Purbeck Beds and marine Upper Jurassic of southern England. Palaeontology 12: 574-620.

Partington, M.A.P., Mitchener, B.C., Milton, N.J. \& Fraser, A.J., 1993a. Genetic sequence stratigraphy for the North Sea Late Jurassic and Early Cretaceous of the North Sea: distribution and prediction of Kimmeridgian-Late Ryazanian reservoirs in the North Sea and adjacent areas. In: Parker, J.R., (ed.), Petroleum Geology of Northwest Europe, Proceedings of the 4th Conference: $347-370$.

Pedersen, K.R., Crane, P.R. \& Friis, E.M., 1989. Pollen organs and seeds with Eucommiidites pollen. Grana, 28: 279-294.

Pedersen, K.R., Crane, P.R., Drinnan, A.N. \& Friis, E.M., 1991. Fruits from the mid-Cretaceous of North America with pollen grains of the Clavatipollenites type. Grana 30: 577-590.

Pedersen, K.R., Friis, E.M. \& Crane, P.R., 1994. Ultrastructure of pollen from Cretaceous angiosperm reproductive structures. In: Kurmann, M.H. \& Doyle, J.A. (Eds), Ultrastructure of fossil spores and pollen. Royal Botanical Gardens Kew: 139-159.

Pelzer, G., 1984. Cross section through fluvial environment in the Wealden of Northwest Germany. Third Symposium on Mesozoic Terrestrial Ecosystems, Tübingen, Short Papers: 181-186.

Pelzer, G. \& Wilde, V., 1987. Klimatische Tendenzen während der Ablagerung der Wealden Fazies in Nordwesteuropa. Geologisches Jahrbuch Serie A, 96: 239-263.

Pelzer, G., Riegel, W. \& Wilde, V., 1992. Depositional controls on the Lower Cretaceous Wealden coals of Northwest Germany. Special Papers of the Geological Society of America 267: 227243. 
Pons, D., 1979. Les organes reproducteurs de Frenelopsis alata (Feistmantel) Knobloch, Cheirolepidiaceae du Cénomanien de l'Anjou, France. Comptes rendus du 104e Congrès National des Sociétés Savantes, Bordeaux 1979, I: 209-231.

Pons, D. \& Broutin, J., 1978. Les organes reproducteurs de Frenelopsis oligostomata (Crétacé, Portugal). Comptes rendus du 103e Congrès National des Sociétés Savantes, Nancy 1978, II: 139-159.

Posamentier, H.W., Jervey, M.T. \& Vail, P.R., 1988. Eustatic controls on clastic deposition I - Conceptual framework. In: Wilgus, C. K. \& Hastings, B. S., (eds), Sea Level Changes; An Integrated Approach. Special Publication of the Society of Economists, Paleontologists and Mineralogists 42: 109-124.

Potonié, R., 1967. Versuch der Einordnung der fossilen Sporae dispersae in das phylogenetischen System der Pflanzenfamilien. Forschungsberichte des Landes Nordrhein-Westfalen, 1761: 11310.

Potonié, R., 1970. Die fossilen Sporen. Ihre morphologische (phylogenetische) neben der morphographischen Ordnung. Forschungsberichte des Landes Nordrhein-Westfalen, 2108: 193.

Poumot, C., 1989. Palynological evidence for eustatic events in the tropical Neogene. Bulletin des Centres de Recherches Exploration-Production Elf-Aquitaine, 13: 437-453.

Raine, J.I., de Jersey, N.J. \& Ryan, K.G., 1988. Ultrastructure and Lycopsid affinity of Densoisporites psilatus (de Jersey) comb. nov. from the Triassic of New Zealand and Queensland. Memoirs of the Association Australasian Palaeontologists 5: 79-88.

Retallack, G.J., 1975. The life and times of a Triassic lycopod. Alcheringa 1:3-29.

Retallack, G.J., 1997. Earliest Triassic origin of Isoetes and quillwort adaptive. Journal of Palaeontology, 71: 35-45.

Reyre, Y., 1980. Peut-on estimer l'évolution des climats Jurassiques et Crétacés d'après la palynologie? Memoirs du Museum National d'Historie Naturelle, Nouveau Serie 27: 247-260.

Runhaar, J., Groen, C.L.G., Van der Meijden, R. \& Stevers, R.A.M., 1987. Een nieuwe indeling in ecologische groepen binnen de Nederlandse flora. Gorteria 13: 277-305.

SIEP, 1995. Standard Ledgend. Shell International Exploration and Production B.V., The Hague.

Skog, J.E. \& Hill, C.R., 1992. The Mesozoic herbaceous Lycopsids. Annals of the Missouri Botanical Gardens, 79: 648-675.

Srivastava, S.K., 1987. Jurassic spore-pollen assemblages from Normandy (France) and Germany. Geobios, 20, 1: 5-79.

Suc, J.-P., 1984. Origin and evolution of the Mediterranean vegetation and climate in Europe. Nature, 307: 429-432.

Targarona, J., 1997. Climatic and Oceanographic evolution of the Mediterranean region over the last Glacial-Interglacial transition. A palynological approach. LPP Contribution Series, 7: 155 pp.

Törnqvist, T. E., 1993 Fluvial sedimentary geology and chronology of the chronology of the Holocene Rhine-Meuse delta, The Netherlands. Ph. D. Thesis, Utrecht: 169 pp.

Tralau, H., 1968. Some middle Jurassic miospores of southern Sweden. Geologiska Föreningens i Stockholm Förhandlingar 89: 469-472.

Traverse, A., 1988. Palaeopalynology, Unwin Hyman, Boston: 600 pp.

Traverse, A., 1994. Sedimentation of palynomorphs and palynodebris: an introduction. In: Traverse, A., Sedimentation of Organic Particles. Cambridge University Press, Cambridge: 1-8.

Tyson, R.V., 1995. Sedimentary organic matter. Chapman and Hall, London: $615 \mathrm{pp}$.

Vail, P.R., Audemard, F., Bowman, S.A., Eisner, P.N. \& PerezCruz, C., 1991. The stratigraphic signatures of tectonics eustacy and sedimentology - an overview. In: Einsele, G., et al. (eds), Cy- cles and events in stratigraphy: $250-275$.

Vakhrameev, V.A., 1970. Pattern of distribution and palaeoecology of Mesozoic conifers Cheirolepidiaceae. Palaeontologicheskij Zhurnal 1: 19-34 (in Russian).

Vakhrameev, V.A., 1991. Jurassic and Cretaceous floras and climates of the Earth. Cambridge University Press, Cambridge: $318 \mathrm{pp}$.

Van Amerom, H.W.J., Herngreen, G.F.W. \& Romein, B.J., 1976. Palaeobotanical and palynological investigation with notes on the microfauna of some core samples from the Lower Cretaceous in the West Netherlands Basin. Mededelingen Rijks Geologische Dienst Nieuwe Serie 27: 41-79.

Van der Burgh, J. \& Van Konijnenburg - Van Cittert, J.H.A., 1984. A drifted flora from the Kimmeridgian (Upper Jurassic) of Lothberg Point, Sutherland, Scotland. Review of Palaeobotany and Palynology 43: 351-396.

Van der Kaars, W.A., 1991. Palynology of eastern Indonesian marine piston-cores: A Late Quaternary vegetational and climatic record for Australasia. Palaeogeography, Palaeoclimatology, Palaeoecology 85: 239-302.

Van der Maarel, E., 1993. Ecosystems of the world 2A. Dry coastal ecosystems. Elsevier Scientific Publishing Company, Amsterdam, Oxford, New York: $600 \mathrm{pp}$.

Van der Zwan, C.J., 2002. The impact of Milankovitch-scale climatic forcing on sediment supply. Sedimentary Geology 147: 271-294.

Van der Zwan, C.J. \& Brugman W.A., 1999. Biosignals from the EA Field, Nigeria. In: Jones, R.W. \& Simmons, M.D. (Eds), Biosignals in production and development geology. Geological Society Special Publication 152: 291-301.

Van Konijnenburg - Van Cittert, J.H.A., 1971. In situ gymnosperm pollen from the Middle Jurassic of Yorkshire. Acta Botanica Neerlandica 20: 1-97.

Van Konijnenburg - Van Cittert, J.H.A., 1978. Osmundaceous spores in situ from the Jurassic of Yorkshire, England. Review of Palaeobotany and Palynology 26: 125-141.

Van Konijnenburg - Van Cittert, J.H.A., 1981. Schizaeaceous spores in situ from the Jurassic of Yorkshire, England. Review of Palaeobotany and Palynology 33: 169-181.

Van Konijnenburg - Van Cittert, J.H.A., 1987. New data on Pagiophyllum maculosum Kendall and its male cone from the Jurassic of North Yorkshire. Review of Palaeobotany and Palynology 51: 95-105.

Van Konijnenburg - Van Cittert, J.H.A., 1989. Dicksoniaceous spores in situ from the Jurassic of Yorkshire, England. Review of Palaeobotany and Palynology 61:273-301.

Van Konijnenburg - Van Cittert, J.H.A., 1991. Diversification of spores in fossil and extant Schizaeaceae. In: Blackmore, $\mathrm{S}$. and Barnes, S.H. (Eds), Pollen and Spores, patterns of diversification. Special Volume of the Systematics Association 44: 103-118.

Van Konijnenburg - Van Cittert, J.H.A., 1993. A review of the Matoniaceae based on in situ spores. Review of Palaeobotany and Palynology 78: 235-267.

Van Konijnenburg - Van Cittert, J.H.A. \& Van der Burgh, J., 1989. The flora from the Kimmeridgian (Upper Jurassic) of Culgower, Sutherland, Scotland. Review of Palaeobotany and Palynology 61: 1-51.

Van Konijnenburg - Van Cittert, J.H.A., \& Van der Burgh, J., 1996. Review of the Kimmeridgian flora of Sutherland, Scotland, with reference to the ecology and in situ pollen and spores. Proceedings of the Geologist's Association 107: 97-105.

Venkatachala, B.S., Kar, R.H., \& Raza, S., 1969. Palynology of the Mesozoic sediments of Kutch, W.India - 3. Morphological study and revision of the spore genus Trilobosporites Pant ex Potonié. Palaeobotanist 17: 123-126. 
Walter, H., 1973. Vegetation of the earth in relation to climate and the eco-physiological conditions. Springer-Verlag New York: 121.

Watson, J. 1988. The Cheirolepidiaceae. In: Beck, C.B. (Ed.), Origin and evolution of Gymnosperms. Columbia University Press: New York: 382-447.

Watson, J. \& Sincock, C.A., 1992. Bennettitales of the English Wealden. The Palaeontographical Society, London: $228 \mathrm{pp}$.

Weiss, M., 1989. Die Sporenfloren aus Rät und Jura SüdwestDeutschlands und ihre Beziehung zur Ammoniten-Stratigraphie. Palaeontographica Abteilung B 215: 1-168.

Wesley, A., 1973. Jurassic plants. In: Hallam, A. (Ed.), Atlas of palaeobiogeography: 329-338.

Whitaker, M.F., Giles, M.R. \& Cannon, J.C., 1992. Palynological review of the Brent Group, UK Sector, North Sea. In: Morton, A.C., Hazeldine, R. S., Giles, M. R. and Brown, S. (eds), Geology of the Brent Group, Geological Society Special Publicatio, 61: 169-202.

Yaroshenko, O.P., 1985. Cavate Lower Triassic spores and their relation to the lycopsids. Palaeontologicheskij Zhurnal 1985: 113119 (in Russian).

Zagwijn, W.H. \& Hager, H., 1987. Correlations of continental and marine Neogene deposits in the south-eastern Netherlands and the Lower Rhine District. Mededelingen Werkgroep Tertiair en Kwartair Geologie 24: 59-78.

Ziegler, P.A., 1990. Geological atlas of Western and Central Europe (2nd edition). Shell International Exploration and Production B.V., The Hague: 239 pp. 